\title{
REFLECTIONS WHILE CHOOSING AN ELECTORAL SYSTEM - THE CASE OF ALBANIA
}

\author{
M. P. Bogdani, F. Bjanku
}

\author{
Mirela P. Bogdani \\ Public Law Department, Law Faculty, \\ University of Tirana, Albania \\ E-mail:mirela_bogdani@yahoo.com

\section{Florian Bjanku} \\ Luigj Gurakuqi University, Shkodra, ALBANIA \\ E-mail: bjanku@gmail.com
}

\begin{abstract}
This paper aims to present some reflections and legal issues that are crucial and should be considered when choosing an electoral system. The paper will present current Albanian legislation and practices in the process of conferring, choosing and implementing the electoral systems in Albania as well as citizens rights and preferences with regards to these issues, as a fundamental pillar of democracy and rule of law.

Albania, as many other post communist countries is going through a long process of democratization of life and institutions and is also facing challenges on its road to EU integration, to tolerant and governments and open-minded society. Elections are very crucial political processes for electing citizens to run the country and take all major decisions on the behalf of the others. Choosing an electoral system according to which votes of citizens will be transformed into seats of Parliament or offices for elected officials is a very complex process that requires consideration from all actors such as political parties, citizens, group of interests, non governmental organizations etc. These actors, being political or non-political ones will need to come up with an elaborated decision for choosing the most appropriate electoral system for a country, since there are many of them implemented all around the world. Factors, elements, issues, citizen's interests, elections formulas and features to be considered when choosing an electoral system, as a matter of choice will be presented more deeply in this paper.
\end{abstract}

Key words: Electoral System, citizens' interest, elections' formulas, democracy, Majoritarian voting system \& Corrected Majoritarian (Albanian case - Parliamentary Elections in Albania in 2001 \& 2005), Proportional System, Regional Proportional System (Albanian case - Parliamentary elections held in Albania in 2009).

\section{Introduction}

\section{A. General Considerations}

Political parties have a preference of the electoral system that favors them and of course lead them to a victory of majority of seats in legislative institutions or elected officials they promote or the ones that are supported by them. In different countries, political parties would prefer proportional representation versus majoritarian one and that is related to the 
size of a political party, the pre and post electoral agreement that parties carry out, the stability of government and the political tradition.

What should be represented in the process of elections? As James Madison stated at The Federalist Papers, No. 10, during the time they were theoretically discussing for the suitable draft of the US Constitution, " ... elected representatives would refine and enlarge the public view ...". Pursuant to democratic theories, the elections allow citizens to appoint or authorize their "representatives" lawfully - "officially authorized representatives" to articulate, verbalize and act in their behalf. In that sense, the institution of electing and selecting a representative that derives from private law ${ }^{1}$, has been transposed into public law.

The main feature of the democracy is plurality of opinions, ideas which are reflected in political organizations, named political parties. Based upon this statement, an electoral system that favors the existence of more and more political parties could be labeled as the most democratic one.

Nowadays, requirements to respect and implement democracy's principles are a certain and maybe the most important feature when an electoral system designed in a country. In this respect, what Madison called "public view" could essentially be interpreted as "public democratic view". Pursuing the argument, Proportional Representation could be ideally the best system to put into practice that democratic principle. This way, all public views will be represented in state institutions or at the parliaments or other legislative institutions $^{2}$ and the minorities views will also be represented; the political specter will be complete.

Another crucial element of democracy is the decision taking and decision making procedure by the majority, whether that is simple majority, absolute majority or qualified majority. In order to have what John Jay had insisted in The Federalists Papers, No. 64, "...the absolute necessity of the system ...", every country, when considers the political structure should be aware of its priorities. Since the time after Second World War, almost all countries inspired amongst peace, security, human rights, political stability of the state's governments. The concern raised is whether Proportional Representation offers political stability. The most common system, used in Canada, India, the United Kingdom, and the United States, is simple plurality, first past the post or winner-takes-all. In this voting system the single winner is the person with the most votes; there is no requirement that the winner gain an absolute majority of votes.

\section{B. Electoral occurrence in Albania}

As many post communist countries, after 1990-s Albania had tried hard to adopt and implement so far different electoral systems in order to ensure democratic principles of the MP-s elections. The electoral system that Albania inherited from communism was simple majoritarian; all Members of the Parliaments of that time were elected by people according to the system first past the post.

\footnotetext{
${ }^{1}$ In the sense of personal mandate by which a person entrusts another person - implying the power of attorney, as institute of private law, when applied electing state officials or Member of Parliament, is being converted into a collective mandate that a nation assigns to the MP-s. These collective mandates, in the beginning were interpreted as "imperative" mandate and later on "representative" mandates.

At the end of nineteenth century, the intervention of Proportional Representation changed the meaning of the term "representation" from a legal to a factual relationship. Parliament came to be thought of as a portrait of the nation, as a small scale of reproduction of the collectivity of the voters. It represents the nation as a portrait represents its model and no longer as the trustee represents his mandatory. Parliament is a small scale reproduction of the whole country, a microcosm in the image of the macrocosm - for more information see Arend LIJPHART \& Bernard Grofman, "Choosing an Electoral System", Issues and Alternatives, American Political Parties and Elections, Co published with the Eagleton Institute of Politics, Rutgers University, PRAEGER, New York Westport. Connecticut, London, ISBN 0-275-91216-7.

${ }^{2}$ Assemblies or Councils that have authority to take major legislative decisions for their countries.
} 
From 1991 - 2001, the electoral system had been Mixed Members Representation MMR, from which $100 \mathrm{MP}-\mathrm{s}$ had been elected directly by voters according to first past post system and 40 remaining MP-s by a proportional formula, that had changed in some elections.

On 2001 Parliamentary elections, the electoral system applied was a mixed one Mixed Member Representation; of the 140 seats of Parliament ${ }^{3}, 100$ should be elected according to formula first past the post and 40 other according to a formula defined at Constitution of Albania and Electoral Law; That system favored mostly the party coalitions and alliances for 40 seats of MP-s.

The same electoral system was applied on Parliamentary elections on 2005. Again, the partie's coalitions made possible that many of the votes for the biggest electoral parties ${ }^{4}$, for the sake of the formula used for 40 remaining seats, were transported to the small parties with whom they had entered into pre electoral agreement ${ }^{5}$. The system used both times ${ }^{6}$, offered stability for the country except few problems came about especially when qualified majority was necessary to elect the President of the Republic on July $2007^{7}$ by Parliament.

On 2008, Albanian Parliament approved a new Electoral Code ${ }^{8}$ based upon the amendments of the Albanian Constitution, Art. 64, where provided the changed electoral system; electoral system was provided only by the Electoral Code and not the Constitution any more. Therefore it changed from Mixed Member Representation to Regional Proportional Representation 9 . The agreement for changing the electoral system was reached mainly by two big political parties SP and DP and disputed by small political parties and non-parliamentary ones. This system favored big parties and of course parliamentary ones and somehow obliged small parties to enter into coalitions in order to win any mandate and other governmental offices as a reward for their contribution into the final elections result.

Due to political fractions that are being created nowadays ${ }^{10}$ and pursuant also to the opinions and views of foreign organizations community, especially EU institutions ${ }^{11}$, there is

\footnotetext{
${ }^{3}$ See Art. 64 of the Albanian Constitution (this article is now amended by removing the electoral system from the constitution's provisions. Therefore the electoral system ins provided by Electoral Law/Code - that means it is easier for political parties to change it every time there is elections), “...One-hundred deputies are elected directly in single-member electoral zones with an approximate number of voters. Forty deputies are elected from the multi-name lists of parties or party coalitions according to their respective order...".

${ }^{4}$ Biggest parties in Albania are considered to be Socialist Party which originates from the existing Party of Labor of Albania / PLA during communism time (it was formed after the dissolution of the PLA on June 1991) and Democratic Party (founded on December 1990) which was created after communism regime collapsed; for more info see http://en/Socialist_Party of_Albania and http://en /Democratic_Party_of_Albania .

${ }^{5}$ The so called "Dushk phenomena" and later on "mega Dushk phenomena".

${ }^{6}$ Mixed member Representation based on the Majoritarian System domination.

${ }^{7}$ For more info on presidential elections, see http://en.presidency.org.

${ }^{8}$ New Electoral Code was approved on December 29, 2008 by mutual accord of two main Albanian political parties and a very intense and serious objections by mid-size and small political parties.

9 Art 64 of the Albanian Constitution provides that "...Parliament will be composed by 140 MP-s, elected according to a proportional system"; Also See part XII of the Electoral Code, Division of Mandates, Art. 163, where provided the formula according to which votes for political parties and coalitions was supposed to be transferred into seats of Parliament.

${ }^{10}$ There are initiatives from some leaders to create new political parties, as fractions of majority - I would like to mention "Red \& Black Alliance", which nowadays represents a social movement focused on protecting human rights of Albanians of the region and all over the world. There are discussions that this social movements could be transformed soon to a political party and compete on 2013 parliamentary elections.

Also, as consequence of political fractions, there had been created the party of "Social Movement for Integration - SMI", as a fraction of Socialist Party of Albania and competed separately during the elections of 2005 and also during other parliamentary and local elections. It influenced into the results, since the SP electorate split into two parties SP and SMI.

${ }^{11}$ Please see Progress Report of EU for Albania, 2009 and Elections Observation Mission Final Elections Report of OSCE / ODIHR of Parliamentary Elections during 2009.
} 
a substantial polarity of Albanian society and more of Albanian politics specter, that should be reduced in order to stabilize the situation in terms of political and social aspect aiming the fulfillment of requirements of Albania for EU integration.

The main issue for Albania is what elements, factors, components and aspects should be considered by political parties, civic society or professional organizations when designing an electoral system for Parliamentary Elections of 2013. When designing an electoral system it is recommended to consider a list of criteria which encapsulate what you want to accomplish, what you want to avoid and, in the very end, what you want your legislature and executive government to look like.

The legislature should be to some degree a "mirror of the nation" ${ }^{12}$, which should look, feel, think and act in a way which reflects the people as a whole. An adequately descriptive legislature would include both men and women, the young and the old, the wealthy and the poor, and reflect the different religious affiliations, linguistic communities and ethnic groups within a society each region, be it a town or a city, a province or an electoral district, has members of the legislature whom it chooses and who are ultimately accountable to their area. The ideological divisions within society may be represented in the legislature, whether through representatives from political parties or independent representatives or a combination of both.

\section{electoral system \\ C 'Building blocks' recommended to be reflected over when designing an \\ I. The electoral system is recommended to Simple and Comprehensible}

Effective and sustainable electoral system designs are more likely to be easily understood by the voter and the politician. Too much complexity can lead to misunderstandings, unintended consequences, and voter mistrust of the results.

\section{The electoral system is recommended to facilitate Stable and Efficient Government}

The expectations for a stable and efficient government are not determined by the electoral system alone. The perception of whether results are fair or not varies widely from country to country ${ }^{13}$. The question whether the government of the day can enact legislation efficiently is partly linked to whether it can assemble a working majority in the legislature, and this in turn is linked to the electoral system. As a general rule, plurality/majority electoral systems are more likely to produce legislatures where one party can outvote the combined opposition, while PR systems are more likely to give rise to coalition governments. Sometimes, it might happen that PR systems can also produce single-party majorities ${ }^{14}$ and plurality/majority systems can leave no one party with a working majority. Much depends on the structure of the party system, the nature of the society itself and the electoral tradition.

III. The electoral system is recommended to increase Voter's Influence

Voters should feel that elections provide them with a measure of influence over governments and government policy. Choice can be maximized in a number of different ways. Voters may be able to choose between parties, between candidates of different parties, and between candidates of the same party. They may also be able to vote under different

\footnotetext{
${ }^{12}$ Electoral System Design / The New International IDEA - Institute for Democracy and Electoral Assistance Handbook, Andrew Reynolds, Ben Reilly and Andrew Ellis, ISBN: 91-85391-18-2, pg. 9, concept of "vivid representation".

${ }^{13}$ I would like to mention here the case of Albania in last Parliamentary Elections, June 2009, where Regional Proportional system was applied; Two main political parties won majority of seats in Parliament but none of them was able to govern. The elections results were a bit contradictory because of the system effects - SP won 620586 votes which were equivalent (according to electoral formula and coalitions formed) to 65 mandates, while DP won 610463 votes equivalent to 68 mandates. For more info see http://www.cec.org.al

${ }^{14}$ Albanian case of Regional Proportional Representation that has similar effects as plurality one, Parliamentary Elections in 2009.
} 
systems when it comes to presidential, upper house, lower house, regional and local government elections. They should also feel confident that their vote has a genuine impact on the formation of the government, not just on the composition of the legislature.

$I V$. The electoral system is recommended to be Accountable

Accountability of electoral system at the individual level - Accountability at the individual level is the ability of the electorate to effectively test on those who, once elected, betray the promises they made during the campaign or demonstrate incompetence or idleness in office. Some systems emphasize the role of locally popular candidates, rather than on candidates nominated by a strong central party.

Plurality/majority systems have traditionally been seen as maximizing the ability of voters to throw out unsatisfactory individual representatives. Again, this sometimes remains valid. Sometimes the connection becomes vague where voters identify primarily with parties rather than candidates. Sometimes open and free list systems are designed to allow voters to exercise candidate choice in the framework of a proportional system.

Accountability of the Government - Accountability is one crucial element of representative government. Its absence may lead to long-term instability. An accountable political system is one in which the government is responsible to the voters to the highest degree possible. Voters should be able to influence the shape of the government, either by altering the coalition of parties in power or by throwing out of office a single party which has failed to deliver. Suitably designed electoral systems could facilitate this objective.

\section{Parties}

$V$. The electoral system is recommended to encourage participation of Political

In a democratic system of government, could that be established or new democracies suggests that longer-term democratic consolidation requires the growth and maintenance of strong and effective political parties, and thus the electoral system should encourage this rather than establish or promote party fragmentation.

Electoral systems can be framed specifically to exclude parties with a small or minimal level of support ${ }^{15}$. Most experts also agree that the electoral system should encourage the development of parties which are based on broad political values and ideologies as well as specific policy programs, rather than narrow ethnic, racial or regional concerns.

\section{Oversight}

VI. The electoral system is recommended to promote Legislative Opposition and

Effective governance depends also on those who oppose and oversee them. An electoral system should help ensure the presence of a viable opposition which can critically assess legislation, question the performance of the executive, safeguard minority rights, and represent its constituents effectively. In this respect, it is recommended as much as possible that opposition groupings should have enough representatives to be effective and in a parliamentary system should be able to present a realistic alternative to the current government. Obviously the strength of the opposition depends on many other factors besides the choice of electoral system, but if the system itself makes the opposition impotent, democratic governance is inherently weakened.

\section{Sustainability of Electoral Process}

Elections do not take place in the academic books but in the real world, and for this reason the choice of any electoral system depends to some degree on the cost and administrative capacities of the country involved. Although donor countries often provide substantial financial support for the first, and even the second, election in a country in transition to democracy, this is unlikely to be available in the long term even if it were

\footnotetext{
${ }^{15}$ This is the case of electoral systems where the minimum threshold for entering the Parliament applied for parties or coalitions.
} 
desirable ${ }^{16}$. A sustainable political framework should take into account the resources of a country both in terms of the availability of people with the skills to be election's administrators and in terms of the financial demands on the national budget.

\section{E. Application of 'International Standards' of elections}

Finally, the design of electoral systems today takes place in the context of a number of international conventions, treaties and other kinds of legal instruments affecting political issues. While there is no single complete set of universally agreed international standards for elections, there is consensus that such standards include the principles of free, fair and periodic elections that guarantee universal adult suffrage, the secrecy of the ballot and freedom from coercion, and a commitment to the principle of one person, one vote.

Moreover, while there is no legal stipulation that a particular kind of electoral system is preferable to another, there is an increasing recognition of the importance of issues that are affected by electoral systems, such as the fair representation of all citizens, the equality of women and men, the rights of minorities, special considerations for the disabled, and so on. These are formalized in international legal instruments such as the 1948 Universal Declaration of Human Rights and the 1966 International Covenant on Civil and Political Rights, and in the various conventions and commitments concerning democratic elections made by regional organizations such as the European Union (EU) and the Organization for Security and Co-operation in Europe (OSCE).

\section{And last but not least ... do not assume that defects can easily be repaired later ${ }^{17}$}

Electoral systems are to be applied for more than two elections. The level of democracy an electoral system offers, the level of citizens 'participation, the level of transparency and also the level of elections administration, is to be evaluated after each electoral system appliance. It is better that electoral systems are designed as per the elements mentioned above; in democracy there is no time for 'fiasco' elections.

All electoral systems create winners and losers, and therefore vested interests. When a system is already in place, these are part of the political environment. At a time of change, however, it may be unwise to assume that it will be easy to gain acceptance later to fix problems which arise. If a review of the system is intended, it may be sensible for it to be incorporated into the legal instruments containing the system change. Take the time needed to get it right the first time.

\section{Conclusions}

The Choice of Electoral System is one of the most important institutional decisions for any democracy. In almost all cases the choice of a particular electoral system has a profound effect on the future political life of the country concerned, and electoral systems, once chosen, often remain fairly constant as political interests solidify around and respond to the incentives presented by them ${ }^{18}$.

Electoral system choice is a fundamentally political process, rather than a question to which independent technical experts can produce a single 'correct answer'. In fact, the consideration of political advantage is almost the main feature in the choice of electoral systems, while the menu of available electoral system choices is often, in reality, a relatively constrained one.

\footnotetext{
${ }^{16}$ Electoral System Design / The New International IDEA - Institute for Democracy and Electoral Assistance Handbook, Andrew Reynolds, Ben Reilly and Andrew Ellis, ISBN: 91-85391-18-2, pg. 13.

${ }^{17} \mathrm{http}: / /$ aceproject.org/ace-en/topics/es/esg

18 IDEA / International Institute for Democracy and Electoral Assistance / Handbook Electoral System Design 2005, ISBN: 91-85391-18-2, page 2. http://www.idea.int/publications/esd/upload/ESD_inlay.pdf
} 
Political institutions shape the rules of the game under which democracy is practiced, and it is often argued that the easiest political institution to manipulate, for good or for bad, is the electoral system. In translating the votes cast in a general election into seats in the legislature, the choice of electoral system can effectively determine who is elected and which party gains power. While many aspects of a country's political framework are often specified in the constitution and can thus be difficult to amend, electoral system change often only involves new legislation.

Albania has traditionally applied electoral systems based upon majoritarian trends, except Parliamentary Elections of 2009 where Regional Proportional system was applied. Still, political parties are aiming to change again the electoral system for next Parliamentary Elections. Electoral systems are living documents that could be amended and changed according to political climate, interests and other circumstances. In that framework, it is recommended to take into account the criteria described above regarding designing process of electoral system. Reforms of the country such as obligations deriving from NATO accession as well as complete integration process to EU require political stability in Albania and region as well, so would be recommended that electoral system applied should offer that stability.

\section{Bibliography}

Albanian Constitution;

Progress Report of EU for Albania, 2009 and Elections Observation Mission Final Elections Report of OSCE / ODIHR of Parliamentary Elections during 2009;

Andrew Reynolds, Ben Reilly, Andrew Ellis (2005), Electoral System Design / The New International IDEA, Institute for Democracy and Electoral Assistance Handbook;

IDEA / International Institute for Democracy and Electoral Assistance / Handbook Electoral System Design 2005;

http://aceproject.org/ace-en/topics/es/esg

http://en /Democratic_Party_of_Albania .

http://en.presidency.org.

http://en/Socialist_Party_of_Albania

http://www.cec.org.al

http://www.idea.int/publications/esd/upload/ESD_inlay.pdf 